Arab World English Journal (AWEJ) Volume 12. Number1 March 2021

Pp. 458- 479

DOI: https://dx.doi.org/10.24093/awej/vol12no1.30

\title{
Student Teachers' Listening Fluency Interaction Patterns: The Use of Similar News Stories in Narrow Listening
}

\author{
Refi Ranto Rozak \\ Post Graduate Program, English Education Department, Universitas Negeri Semarang (UNNES), \\ Indonesia \\ Under graduate Program, English Education Department, IKIP PGRI Bojonegoro, Indonesia \\ Correspondent Author: refi.ranto@ikippgribojonegoro.ac.id
}

Mursid Saleh

Post Gradute Program, English Education Department

Universitas Negeri Semarang (UNNES), Indonesia

Dwi Anggani Linggar Bharati

Post Gradute Program, English Education Department

Universitas Negeri Semarang (UNNES), Indonesia

Djoko Sutopo

Post Gradute Program, English Education Department

Universitas Negeri Semarang (UNNES), Indonesia

Received: $11 / 6 / 2020$

Accepted: 1/12/2021

published:3/24/2o21

\section{Abstract}

This article reports the use of similar news stories in narrow listening in an Extensive Listening course to promote student teachers' listening fluency in an Indonesian initial teacher education context. This study was to investigate: (1) What is the patterns of interaction of Indonesian student teachers of English regarding their listening fluency when exposed to slow, moderately slow, and normal speech level texts?; and (2) What are the challenges and opportunities of promoting listening fluency through narrow listening using news stories in an Extensive Listening course? The aims of this article are to portray student teachers' listening fluency interaction patterns through similar news stories in narrow listening and to investigate the challenges and opportunities of promoting listening fluency using narrow listening. This sequential mix-method study reported 40 student teachers' engagement in extensive listening activities over 12 weeks, such as: (1) the choice of the news stories using online extensive listening material selection survey, (2) repeated listening tasks for fluency development at a lower to a normal speech rate level, and (3) linked-skills fluency development activities scaffolded by the teacher educators. The study found that similar news stories in narrow listening as extensive listening material helped student teachers familiarize similar structures and vocabulary of the spoken texts from similar topics/themes. The article portrays the inclusion of narrow listening in an Extensive Listening course can help the development of student teachers' listening fluency in Indonesian initial Teacher Education context.

Keywords: Extensive listening, initial teacher education, interaction patterns, listening fluency, narrow listening, news stories, repeated listening, student teachers

Cite as: Rozak, R. R., Saleh, M., Bharati, D. A. L., \& Sutopo, D. (2021). Student Teachers' Listening Fluency Interaction Patterns: The Use of Similar News Stories in Narrow Listening . Arab World English Journal, 12 (1) 458- 479 . DOI: https://dx.doi.org/10.24093/awej/vol12no1.30 
Arab World English Journal (AWEJ) Volume 12. Number 1. March 2021

Student Teachers' Listening Fluency Interaction Patterns

Rozak, Saleh, Bharati, \& Sutopo

\section{Introduction}

In recent years, promoting listening fluency has been of great concern among language teachers. Listening fluency inclusion in language teachers' listening curriculum allows students to process the spoken texts effortlessly, accurately, and comprehensively to reach a reasonable degree of comprehension. In this regard, students need a lot of spoken inputs and continuous practices to attain this level of proficiency (Rost, 2006). Extensive listening provides students abundant exposure to spoken texts as the language input and simultaneous practices that lead to listening fluency. Ducker \& Saunders (2014) pointed out that extensive listening is a process by which language learners can increase their proficiency in listening and acquire a second language (L2) through access and exposure to texts which are simultaneously understandable and enjoyable. The fundamental principle of extensive listening is listening might be best learned through listening. This is relevant to Ridgway (as cited in Renandya, 2011) that practising listening for communicative purposes is important to develop students' listening skills and automaticity.

Promoting listening fluency in an Extensive Listening course is a novel idea. Even though extensive listening to second language (L2) teaching has been widely researched worldwide (Alm, 2013; Bidabadi \& Yamat, 2014; Blyth, 2012; Bozan, 2015; Chang, 2012; Chang, 2018; Lee \& Cha, 2017; Masrai, 2019; Pamuji, Waring, \& Kurniawan, 2019; Renandya, 2012; Renandya \& Jacobs, 2016; Renandya \& Ivone, 2019; Takaesu, 2013; Yeh, 2013; Zeng \& Goh, 2018) and the impacts of extensive listening on the L2 and English as a foreign language (EFL) students' listening fluency (Chang, 2011; Chang \& Millet, 2014; Chang \& Millet, 2016; Chang, Millet, \& Renandya, 2018; Tsai, 2019), it is unfortunate that there are minimal data found in the literature discussing extensive listening in Indonesian initial teacher education contexts. Not until recently did Widodo \& Rozak (2016) conducted a qualitative investigation into the use of online videos for extensive listening coupled with reflective practice and online discussions. However, although extensive listening starts to be a promising study in an Indonesian initial teacher education context, promoting listening fluency as the primary goal of extensive listening has not been discussed and documented in this context. Additionally, although listening fluency is an important strand in language proficiency, it has not been incorporated into listening instruction because it is not a legitimate institution curriculum yet.

To fill the literature gaps, it is indispensable for teacher educators to inserting listening fluency in an Extensive Listening course in an initial teacher education context. Listening fluency inclusion purpose in an Extensive Listening course is to train student teachers' automaticity in processing the various spoken texts found in a real-life situation using authentic materials. In this case, they practice how to decode aural elements automatically between the speakers and listeners for sharing the ideas in a two way communication. During the process of communication, listeners have no time to stop what is being said by the speaker because the listening process is completely automatic (Chang \& Millet, 2016). Therefore, they do not only learn some comprehension skills and strategies in the classroom but they should develop their language proficiency by practicing how to process spoken language with ease and automaticity. Listening fluency training approaches in an Extensive Listening course is considered to help students practice processing a fast rate found in real life listening.

Narrow listening (derived from narrow reading) is one of approaches to develop students' listening fluency. Krashen (1996) defined narrow listening as listening to a lot of comprehensible input through repeated listening, self-selection of samples, and familiarity with the topics. 
Arab World English Journal (AWEJ) Volume 12. Number 1. March 2021

Student Teachers' Listening Fluency Interaction Patterns

Rozak, Saleh, Bharati, \& Sutopo

Repeated listening (repeatedly listening to a text until the learner can fully understand without referring to the written text) is regarded as a useful support in facilitating students' comprehension in the teaching of listening and doing the listening tests (Chang \& Read, 2006). Besides, topic familiarity coming from one single author or topic is also stressed in narrow listening. It is helpful for building learners' comprehension by allowing them to recognize similar structures and vocabulary of spoken texts (Rodrigo, 2003). Narrow listening also enables learners to listen the exciting topics at their pace so that they take care of their language acquisition. Regarding to listening fluency development, narrow listening can be molded by the multiple exposure to the same input, multi- channel exposure (audio and text), and spaced repetitions.

To extend this scholarship, this article is framed as listen fluency development tasks reaped from the principles of extensive listening and narrow listening. More importantly, student teachers' listening development is trained through engaged and scaffolded repetitions for developing their automaticity using understandable and enjoyable listening inputs for making meaning. This study used similar news stories as authentic materials through engaging various extensive listening activities. To frame a prominent picture of how teaching listening fluency for student teachers using narrow listening in an Extensive Listening course, this article highlights such critical issues as: (1) What are the patterns of interaction of Indonesian student teachers of English regarding their listening fluency when exposed to slow, moderately slow, and normal speech level texts?; and (2) What are the challenges and opportunities of promoting listening fluency through narrow listening using similar news stories in an Extensive Listening course?. The results of the study can be beneficial contribution for both teacher educators and student teachers in recognizing the interaction patterns of listening fluency through similar news stories in narrow listening and in investigating the challenges and opportunities of promoting listening fluency using narrow listening.

\section{Literature Review}

\section{Previous Studies}

The previous studies related to the effects of extensive listening on learners' listening fluency in L2 and EFL listening are reported by recent articles in the past ten years. Although the empirical reviews of listening fluency in extensive listening is a relatively novel idea in both L2 and EFL listening instruction (Chang, 2011; Chang \& Millet, 2014; Chang \& Millet, 2016; Chang, Millet, \& Renandya, 2018; Tsai, 2019), there is still a small body of previous research on the use of narrow listening in university students, especially student teachers of English in initial teacher education institutions. More specifically, there has not been a research done to examine and investigate the patterns of interaction of Indonesian student teachers of English regarding their listening fluency in graded speech rate levels. Drawing on library databases, some relevant studies were reported.

First, a most recent study by Chang (2019) looked into five fixed factors (time, frequency of word occurrence, glossing, word frequency levels, and four dimensions of vocabulary understanding from narrow reading and listening). Both understanding of written and aural meaning significantly improved rather than spelling and using the target word appropriately. The low- frequency word levels are well-acquired and maintained than those in high frequency word levels. Words containing glosses are acquired better than those with no glosses. Overall, this study suggests that narrow reading and listening helped students comprehend the texts smoothly 
Arab World English Journal (AWEJ) Volume 12. Number 1. March 2021

Student Teachers' Listening Fluency Interaction Patterns

Rozak, Saleh, Bharati, \& Sutopo

from level one to level three by reading one related text at each level. Second, narrow listening's effect on ninety-five first-year tertiary-level students of English as a second language (ESL) in Hong Kong was reported by Tsang (2019). This three-month experimental research revealed that experimental groups' pronunciation and fluency in reading aloud, performing dialogues, and free production significantly improved after the experimentation than control group. Third, Mayora (2016) reported the implementation of a small scale of narrow listening among 24 student teachers of English and French in a Colombian university during 11 weeks. The study looked into the process, the product, and the perceptions of the small scale of narrow listening scheme. This study found that the process of the learning scheme used authentic similar news report videos self-selection, videos information collection by using extensive listening worksheets, and audio journal completion via podcasts. Fourth, Shahrokhi et al. (2013) investigated voicing strategies employed in narrow listening among 12 Iranian female freshmen. The result of the participants' selection revealed that Iranian EFL female freshman university learners' top-down, bottom-up processing and listening strategy awareness should be cultivated and integrated into the teaching of listening to improve the learners' listening ability.

On the other hand, the empirical reviews of listening fluency in extensive listening is a relatively novel idea in L2 even in the EFL language instruction (Chang, 2011; Chang \& Millet, 2014; Chang \& Millet, 2016). Chang (2011) reports 26 weeks investigation of 19 Taiwanese EFL students in a listening course. She investigated the effect of reading while listening (RwL) than usual formal listening instruction on students' listening fluency and vocabulary gain. The findings showed that RwL class outperformed the control group in both vocabulary gain and listening scores in vocabulary level test and listening test delivered at a speech rate of 160 word per minute (wpm). Similar issue by comparing three different inputs, such as reading only, reading while listening, and listening only to audio-graded readers was reported by Chang \& Millet (2016). She conducted the study among 113 a low-intermediate EFL university students in English proficiency courses over a 13 -week period. The post-test result after the intervention indicated that reading while listening group score in listening fluency items (180 items) is significantly better than reading only and listening only group. Simultaneous reading plus writing is very helpful to support students word recognition and aural discrimination. Tsai (2019) also researched the importance of digital audiobooks in enhancing 112 undergraduates' listening fluency. Drawing on reading and while listening to audiobooks as authentic materials, this study found that students' listening fluency and comprehension improved after pedagogical mediation. Lastly, Chang \& Millet (2016) investigated the effects on developing L2 listening fluency through extended listening-focused after reading and listening to audio graders. The study concluded that the amount of input and the frequency of practice from simultaneous input and single input in listening led to the higher improvement of listening.

Even though the reported studies show a positive enhancement regarding the use of narrow listening in the various ESL/EFL contexts, the need for examining narrow listening on learners' listening fluency remains non-existent. Thus far, no empirical evidences have critically looked into how narrow listening is able to improve student teachers' listening fluency in an Extensive Listening course in the ESL/EFL contexts from quantitative and qualitative approaches. To fill this gap, the current study attempts to continue this scholarship of narrow listening, especially in an Indonesian initial teacher education institution. To better understand the benefits of narrow listening, this study is framed as linked-skills listening fluency development activities in an Extensive Listening course using in-and out-of classroom activities. 
Arab World English Journal (AWEJ) Volume 12. Number 1. March 2021

Student Teachers' Listening Fluency Interaction Patterns

Rozak, Saleh, Bharati, \& Sutopo

\section{Methods}

The current study employed an explanatory sequential mix-methods design (Cresswell, 2014). The rationale of using this design because this study garnered the data from the participants' responses from the extensive listening material survey and weekly and the final listening fluency tests. Furthermore, the qualitative data obtained from follow-up interviews were collected for an in-depth understanding of the participants' perceptions and experiences to the study as well.

\section{Research Context and Participants}

The study was conducted from Apri to July 2018 in English Education and Training Department at an initial Teacher Education in East Java Province, Indonesia. There are three prescribed listening courses offered in the department: Intensive Listening, Academic Listening, and Extensive Listening. In Intensive Listening, student teachers are trained to listen to short bits of spoken language intensively which adopts comprehension approach, spoken language features, and simple conversations. In Academic Listening, they are provided with listening practices by identifying general and specific information from long lectures in the various fields, such as seminars, conferences, and academic debates. In Extensive Listening, student teachers learn how to enhance their listening fluency through the various authentic listening materials at an upper-intermediate and pre-advanced level using a top-down approach with different speech rates for developing student teachers' listening fluency.

The current study was part of Extensive Listening course. This course took a quarter of class time or approximately 1.5 of 6 odd semester duration in academic year 2018/2019. This course was offered in the third term (Year 2). As language student teachers are prepared to be professional English language teachers, they needed to experience with how listening fluency could be included in the learning activities. The study aimed to portray student teachers' listening fluency training through scaffolded similar news stories from slow (120 wpm), moderately slow $(130,140$, and $150 \mathrm{wpm})$, and average or a normal (160 wpm) speech level.

Out of 57 student teachers, 40 participants (15 males and 25 females) consented to engage voluntarily in the project. They were well-informed of the project and duly signed a consent form before their participation in this study. The participants were multilingual with competencies in Javanese and Bahasa Indonesia. Their English proficiency was at lowintermediate level. It was shown by their TOEFL scores when they first entered the department. The age range of the participants was between 19 and 22 years old. They previously experienced with extended listening activities in extensive listening, such as viewing English videos via TedTalks and Youtube. They attended a three-days second-semester courses every week offered by the English Department. 15 participants agreed to attend one to one interview after the project to report their reactions to the extensive listening project using similar news stories and scaffolded fluency development activities. For ethical consideration, their names were given pseudonyms in this paper.

\section{Instruments}

Similar news stories were preferred as the materials in this article because they fulfilled the extensive listening material requirements, such as: authentic, unmodified, famous, and spontaneous. The main consideration of choosing similar news stories as the learning materials was also because they contained serial information for similar topics as they were anchored in narrow listening principle. In this respect, the topics of the news stories were related to the 
Arab World English Journal (AWEJ) Volume 12. Number 1. March 2021

Student Teachers' Listening Fluency Interaction Patterns

Rozak, Saleh, Bharati, \& Sutopo

Mount Agung Eruption news headlines broadcasted by national and international renowned mass media between August 2017 to February 2018. For the sake of listening audio materials, the authors recruited a native speaker of English as a human reader who was assigned to read the written news stories in a professional dubbing studio. To set the speech of each news story production, the operator of the studio converted the speech to speed up and slow down to achieve the desired wpm (words per minute) counts. To put it another way, the speech rates of the audio were converted into slow (120 wpm), moderately slow $(130,140$, or $150 \mathrm{wpm})$, and average or a normal $(160 \mathrm{wpm})$ speech level. All the converted news stories audio with different speech rate levels were then stored in Extensive Listening course online platform called Canvas for student teachers' listening material references.

The empirical data were collected through the extensive listening material survey using Google doc., listening logs, listening comprehension tests, and interview sheets. The extensive listening material survey was used by the participants to select their preferential news story topics. Furthermore, listening logs were used to record the number of repetitions of the news stories in different levels of speech rate. In this regard, they marked their comprehension in each repetition among $5=(100-90 \%), 4=(89-70 \%), 3=(69-50 \%), 2=(49-30 \%)$, or $1=($ below $30 \%)$. If they felt that their comprehension was fewer, they could repeat listening to the whole audio of the news story or listen some probelmatic parts of listening and scored their comprehension in the later repetitions. As suggested by the authors as the teacher educators in the study, the participants should ensure that their comprehension was above 90\% which means that the preferred news stories were suitable for extensive listening materials. If after repeating the news story several times and their comprehension scores were below $90 \%$ means the news stories were not recommended to be selected as extensive listening materials.

To measure the participants' listening fluency test after listening each news story, the participants also should answer some multiple choice questions. It aimed to score their comprehension in each speech rate after listening to news story. There were three indicators in this test, such as listening for gist, listening for specific information, and listening for inferences. These indicators were all distributed in 10 multiple choice items for each news story. Lastly, the interview sheet was used as a guideline in interview sessions conducting in the end of the study to investigate participants' perceptions and experiences regarding to listening fluency development activities in an Extensive Listening course using narrow listening. Totally, there were ten questions in the interview but, for the purpose of the study, responses to the challenges and opportunities of promoting listening fluency through narrow listening using similar news stories in this study were the main issues of the interview.

\section{Procedures}

In the beginning, the participants took part in a course orientation. In this course stage, the participants were introduced the learning objectives, the concept of extensive listening and narrow listening, and the practice of self-selecting similar news stories as extensive listening materials on Google Survey. In particular, filling out the survey was the important stage of this study. They should determine which news stories were suitable for their comprehension level. There are six criteria in the survey: 1) the significance of the news story; 2) the interest in information available in the news story; 3) the language level of the news story (whether between 90 - 95); 4) the ability of the participants without having to stop the audio; 5) the difficulty level of news story content; and 6) the engagement of the participants in the news story 
Arab World English Journal (AWEJ) Volume 12. Number 1. March 2021

Student Teachers' Listening Fluency Interaction Patterns

Rozak, Saleh, Bharati, \& Sutopo

language features. To match the principle of extensive listening material, the survey helped participants to self-select the appropriate extensive listening materials. They should tick 'yes' or ' $n o$ ' in each criterion in the survey after listening to the news story audio and ensure whether or not it had been met their language proficiency levels. A 'yes' answer to all criteria would mean that the news story was suitable for extensive listening activities. On the contrary, a negative answer to the criteria means that the news story is incomprehensible or uninteresting. Therefore, the participants should re-select other news story and marked all criteria in the survey again until the understandable news story was preferred.

They should self-select ten different news story topics as their extensive listening materials. From the preferred news story topics, the author then classified the participants according to their topic selection interest. Furthermore, they engaged in listening fluency development tasks using linked-skills activities within three stages of listening instructional scenario which consisted of the pre-listening stage (background understanding activation of the topic), the whilst-listening stage (repeated listening and collaborative reading and speaking), and the post-listening stage (collaborative writing) (See Table one). In particular, in the beginning of the core classroom activities, they were given questions to activate their background understanding about the news story topic in the pre-listening stage. In the whilst-listening stage, they self-listened to the topical news stories at slow $(120 \mathrm{wpm})$, moderately slow $(130,140$, and $150 \mathrm{wpm})$, and average or a normal (160 wpm) speech level in Extensive Listening online course platform. They should also mark their comprehension whether below 30\%, 49-30\%, 69-50\%, 89$70 \%$ or $100-90 \%$ in each repetition using listening logs. They could repeat some points that they did not understand and then mark again their listening comprehension level in the listening logs.

Table 1. Linked skills activities in listening fluency development tasks

Preliminary Course

1. Familiarizing participants with learning objectives and the concepts of narrow listening and extensive listening;

Orientation 2. Practicing self-select news stories as extensive listening materials using Google Survey;

course

3. Self-selecting news stories as extensive listening materials in the course online platform database;

4. Classifying the participants according to the selected news story topics for collaborative learning

\begin{tabular}{|c|c|c|}
\hline Stages & $\begin{array}{l}\text { Weekly linked-skills } \\
\text { Activities }\end{array}$ & Details \\
\hline $\begin{array}{l}\text { Pre-listening } \\
\text { stage }\end{array}$ & $\begin{array}{l}\text { Background knowledge } \\
\text { activation }\end{array}$ & $\begin{array}{l}\text { Activating participants' background knowledge of the news story } \\
\text { through topic-related pictures or videos }\end{array}$ \\
\hline \multirow{3}{*}{$\begin{array}{l}\text { Whilst- } \\
\text { listening stage }\end{array}$} & $\begin{array}{l}\text { Listening to graded similar } \\
\text { news stories from slow to } \\
\text { normal speech rate levels } \\
\text { (listening) }\end{array}$ & $\begin{array}{l}\text { The participants listened to graded similar news stories at slow } \\
(120 \text { wpm), moderately slow (130, 140, and } 150 \mathrm{wpm}) \text { and } \\
\text { average or a normal }(160 \mathrm{wpm}) \text { speech rate level using listening } \\
\text { logs to check their comprehension. In this listening log, they } \\
\text { should mark their comprehension whether below } 30 \%, 49-30 \% \text {, } \\
69-50 \%, 89-70 \% \text { or } 100-90 \% \text { in each repetition. }\end{array}$ \\
\hline & $\begin{array}{l}\text { Collaborative reading } \\
\text { (reading) }\end{array}$ & $\begin{array}{l}\text { The participants grouped collaborative reading with similar news } \\
\text { story topics. They read aloud their news story transcripts and } \\
\text { selected a group representative to read aloud to the whole class in } \\
\text { turn. }\end{array}$ \\
\hline & $\begin{array}{l}\text { Collaborative speaking } \\
\text { (speaking) }\end{array}$ & $\begin{array}{l}\text { In pair, similar news story topic groups took turns telling and } \\
\text { checking the main points of the selected news stories they had } \\
\text { just listened to. }\end{array}$ \\
\hline Post-listening & Dictogloss collaborative & Similar news story topic groups recycled the vocabulary used in \\
\hline
\end{tabular}


Arab World English Journal (AWEJ) Volume 12. Number 1. March 2021

Student Teachers' Listening Fluency Interaction Patterns

Rozak, Saleh, Bharati, \& Sutopo

\begin{tabular}{lll}
\hline & \multicolumn{2}{c}{ Preliminary Course } \\
\hline & $\begin{array}{l}\text { 1. } \begin{array}{l}\text { Familiarizing participants with learning objectives and the concepts of narrow listening and } \\
\text { extensive listening; }\end{array} \\
\begin{array}{l}\text { Orientation } \\
\text { course }\end{array}\end{array}$ & $\begin{array}{l}\text { 2. } \begin{array}{l}\text { Practicing self-select news stories as extensive listening materials using Google Survey; } \\
\text { 3. Self-selecting news stories as extensive listening materials in the course online platform } \\
\text { database; }\end{array} \\
\text { 4. Classifying the participants according to the selected news story topics for collaborative } \\
\text { learning }\end{array}$ \\
\hline Stages & $\begin{array}{l}\text { Weekly linked-skills } \\
\text { Activities }\end{array}$ & \multicolumn{1}{c}{ Details } \\
\hline stage & writing (Writing) & $\begin{array}{l}\text { the previous news stories and rewrote them into the other similar } \\
\text { news stories }\end{array}$ \\
\cline { 2 - 3 } & Final evaluation & $\begin{array}{l}\text { The participants individually had an evaluation by listening to the } \\
\text { topical similar news story in normal speech rate level (160 wpm) }\end{array}$ \\
\hline
\end{tabular}

\section{Data Analysis}

The collected data were analyzed using quantitative and qualitative approaches. There are three kinds of quantitative data in this article, i.e., the number of participants' responses from news stories material selection via Google Survey, the number of listening repetitions and listening fluency scores in each weekly graded listening sessions, and the final listening fluency tests. Specifically, in analyzing the number of participants' responses from Google Survey, out of 30 available Mount Agung Eruption-related to news stories headlines were available in the Extensive Listening online course material database to select. 10 out of 30 news story headlines were then automatically analyzed by Google Survey. These 10 preferred Mount Agung Eruptionrelated news stories headlines had fulfilled as good extensive listening materials criteria indicated by total positive responses ('yes' selection).

The analysis of participants' listening repetitions and their listening fluency scores in each graded listening session were analyzed by counting the total number of participants' listening repetitions and the total listening fluency in each graded listening divided by the number of participants to obtain the average participants' listening repetitions and listening fluency scores. Moreover, the final listening fluency test scores were analyzed by counting the total number of participants' listening comprehension test scores $(160 \mathrm{wpm})$ and divided by the number of participants each group. On the other hand, the qualitative data were obtained from participants' interview responses. There were two steps of analysis. Firstly, the data collected from participants' responses were analyzed and then the main thematic categories were identified. Secondly, the data from their responses were then compared and contrasted and larger thematic categories were extracted.

\section{Findings}

The patterns of interaction of Indonesian student teachers of English regarding their listening fluency

The result of the participants' extensive listening material survey

Drawing on a mix-method study, we identified some emergent quantitative and qualitative findings. However, before main findings related to the questions of the study are presented, the following Table 2 is the result of preliminary data collection in terms of the participants' extensive listening material survey preference.

Table 2. The Survey result of extensive listening materials selection

\begin{tabular}{llllllllll}
\hline No & News stories (NSs) main titles & $n$ & C1 & C2 & C3 & C4 & C5 & C6 & Average \\
\hline
\end{tabular}


Arab World English Journal (AWEJ) Volume 12. Number 1. March 2021

Student Teachers' Listening Fluency Interaction Patterns $\quad$ Rozak, Saleh, Bharati, \& Sutopo

\begin{tabular}{|c|c|c|c|c|c|c|c|c|c|}
\hline & & & $\%$ & $\%$ & $\%$ & $\%$ & $\%$ & $\%$ & $\%$ \\
\hline 1 & Local News Report Hoax on Eruption & 51 & 96.1 & 100 & 94.1 & 96.1 & 96.1 & 94.1 & 96.08 \\
\hline 2 & $\begin{array}{l}\text { Bali Offers Up to } 50 \text { Percent Discounts } \\
\text { to Stranded Tourists: Minister of } \\
\text { Tourism }\end{array}$ & 44 & 100 & 97.7 & 97.7 & 97.7 & 100 & 97.7 & 98.47 \\
\hline 3 & $\begin{array}{l}\text { Government Prepares } 5 \text { Airports Near } \\
\text { Bali Island Anticipating Mt. Agung } \\
\text { Eruption }\end{array}$ & 41 & 95.1 & 100 & 100 & 100 & 90.2 & 92.7 & 96.33 \\
\hline 4 & $\begin{array}{l}\text { Bali Volcano Update: Eruption } \\
\text { Imminent on Mt. Agung }\end{array}$ & 44 & 95.5 & 93.2 & 97.7 & 97.7 & 95.5 & 97.7 & 96.21 \\
\hline 5 & $\begin{array}{l}\text { Indonesian Condemns Tavel Advisory } \\
\text { as Excessive amid Bali Volcano } \\
\text { Eruption }\end{array}$ & 45 & 93.3 & 93.3 & 91.1 & 91.1 & 93.3 & 95.6 & 92.95 \\
\hline \multicolumn{9}{|c|}{ Overal average } & 96.008 \\
\hline
\end{tabular}

Note: $n=$ respondents, $C 1=$ criteria $1, C 2=$ criteria $2, C 3=$ criteria $3, C 4=$ criteria $4, C 5=$ criteria $5, C 6=$ criteria 6

Based on the extensive listening material survey distributed to the respondents, there were five news stories main headlines which they likely chose according to the extensive listening material selection criteria. The total average percentage of respondents' news stories selection is $96.008 \%$. It means that the preferred news stories had been comprehensible and suitable to the respondents' proficiency levels. Furthermore, we provided similar news stories topics relevant to the respondents' preferred news stories headlines for in- and out-of classroom learning as described in Table 3.

Table 3. The topical similar news stories

\begin{tabular}{|c|c|c|c|c|}
\hline No. & $\begin{array}{l}\text { Main news stories } \\
\text { (NSs) headlines }\end{array}$ & & Weekly similar news stories (NSs) topics & $\begin{array}{c}\text { Similar news story topics } \\
\text { for the final listening } \\
\text { fluency test }\end{array}$ \\
\hline \multirow{5}{*}{ 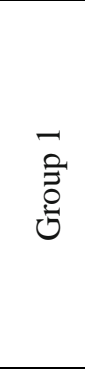 } & \multirow{5}{*}{$\begin{array}{l}\text { Local News Report } \\
\text { Hoax on Eruption }\end{array}$} & 1.1 & $\begin{array}{l}\text { Hoax Not Helping as Mount Agung } \\
\text { Eruption Looms in Bali }\end{array}$ & \multirow{5}{*}{$\begin{array}{l}\text { Bali Accuses Competitors } \\
\text { of Spreading Hoaxes about } \\
\text { Volcano }\end{array}$} \\
\hline & & 1.2 & $\begin{array}{l}\text { BNPB: Do Not Believe Hoax about } \\
\text { Mount Agung Eruption }\end{array}$ & \\
\hline & & 1.3 & $\begin{array}{l}\text { Indonesian Police Hunts Individuals } \\
\text { Spreading Hoax on Mount Agung }\end{array}$ & \\
\hline & & 1.4 & $\begin{array}{l}\text { Keep Calm and Enjoy Bali: Tourism } \\
\text { Association }\end{array}$ & \\
\hline & & 1.5 & Fake News and Mount Agung & \\
\hline \multirow{5}{*}{ 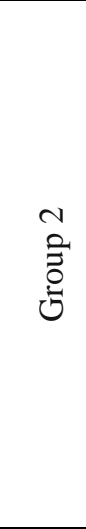 } & \multirow{5}{*}{$\begin{array}{l}\text { Bali Offers Up to } \\
50 \text { Percent } \\
\text { Discounts to } \\
\text { Stranded Tourists: } \\
\text { Minister of Tourism }\end{array}$} & 1.1 & $\begin{array}{l}\text { Tourism Minister Angry that Hotels Are } \\
\text { Not Discounting Room Rates Enough } \\
\text { During Mount Agung Eruption Period }\end{array}$ & \multirow{5}{*}{$\begin{array}{l}\text { Indonesia’s Tourism } \\
\text { Minister Urges Hotels to } \\
\text { Give Special Discounts to } \\
\text { Tourists Stranded in Bali }\end{array}$} \\
\hline & & 1.2 & $\begin{array}{l}\text { Indonesia Offers up to } 50 \text { Percent } \\
\text { Discounts for Tourists Traveling to Bali }\end{array}$ & \\
\hline & & 1.3 & $\begin{array}{l}32 \text { Hotels in Lombok Offer Discounts of } \\
\text { up to } 50 \text { Percent }\end{array}$ & \\
\hline & & 1.4 & $\begin{array}{l}\text { Tourism Minister Urges Discounts for } \\
\text { Tourists Trapped in Bali Due to Mt. } \\
\text { Agung Eruption }\end{array}$ & \\
\hline & & 1.5 & $\begin{array}{l}\text { Tourism Minister Asks Bali Hotels to } \\
\text { Give Discounts to Stranded Guests after } \\
\text { Mt. Agung Erupts }\end{array}$ & \\
\hline $0=$ & Government & 1.1 & Alternative & Indonesia Prepares 10 \\
\hline
\end{tabular}


Arab World English Journal (AWEJ) Volume 12. Number 1. March 2021

Student Teachers' Listening Fluency Interaction Patterns $\quad$ Rozak, Saleh, Bharati, \& Sutopo

\begin{tabular}{|c|c|c|c|c|}
\hline & \multirow{8}{*}{$\begin{array}{l}\text { Prepares } 5 \text { Airports } \\
\text { Near Bali Island }\end{array}$} & \multicolumn{2}{|r|}{ Anticipate Gunung Agung Situation } & \multirow{8}{*}{$\begin{array}{l}\text { Airports to Deal with Bali } \\
\text { Volcano Eruption }\end{array}$} \\
\hline & & 1.2 & $\begin{array}{l}\text { Nine Airports Prepared in Anticipation } \\
\text { of Mount Agung Eruption }\end{array}$ & \\
\hline & & 1.3 & $\begin{array}{l}\text { Airnav Sets } 10 \text { Backup Airports Nearing } \\
\text { Mt. Agung Eruption in Bali }\end{array}$ & \\
\hline & & & Nine $\quad$ Airports $\quad$ Prepared by & \\
\hline & & 1.4 & Transportation Ministry Anticipating & \\
\hline & & & Volcanic Activity of Mount Agung & \\
\hline & & 1.5 & 10 Alternative Airports Prepared & \\
\hline & & 1.5 & Anticipate Gunung Agung Situation & \\
\hline \multirow{5}{*}{ 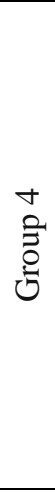 } & \multirow{5}{*}{$\begin{array}{l}\text { Bali Volcano } \\
\text { Update: Eruption } \\
\text { Imminent on Mt. } \\
\text { Agung }\end{array}$} & 1.1 & $\begin{array}{l}\text { Bali Volcano Latest: Eruption Imminent- } \\
\text { Mount Agung about to Blow at Any } \\
\text { Moment }\end{array}$ & \multirow{5}{*}{$\begin{array}{l}\text { Bali Volcano Eruption } \\
\text { 'Imminent,' Nearly 50,000 } \\
\text { Flee }\end{array}$} \\
\hline & & 1.2 & $\begin{array}{l}\text { Bali issues Red Alert Fearing Imminent } \\
\text { Larger Eruption of Mount Agung } \\
\text { Volcano }\end{array}$ & \\
\hline & & 1.3 & $\begin{array}{l}\text { Bali Volcano-Indonesia Fears Imminent } \\
\text { Mt. Agung Eruption }\end{array}$ & \\
\hline & & 1.4 & $\begin{array}{l}\text { Bali Volcano-Larger Eruption Could be } \\
\text { Imminent }\end{array}$ & \\
\hline & & 1.5 & $\begin{array}{l}\text { Mt. Agung Eruption Could be Imminent: } \\
\text { Agency }\end{array}$ & \\
\hline \multirow{5}{*}{$\underset{0}{0}$} & \multirow{5}{*}{$\begin{array}{l}\text { Indonesian } \\
\text { Condemns Tavel } \\
\text { Advisory as } \\
\text { Excessive amid } \\
\text { Bali Volcano } \\
\text { Eruption }\end{array}$} & 1.1 & $\begin{array}{l}\text { Singaporeans Urged to Postpone Travel } \\
\text { to Bali amid Mount Agung Eruption }\end{array}$ & \multirow{5}{*}{$\begin{array}{l}\text { MFA Advises Singaporeans } \\
\text { to Defer Travel to Bali as } \\
\text { Situation on Mount Agung } \\
\text { Remains Unpredictable }\end{array}$} \\
\hline & & 1.2 & $\begin{array}{l}\text { Defer Travel to Bali amid Unpredictable } \\
\text { Situation on Mount Agung: MFA }\end{array}$ & \\
\hline & & 1.3 & $\begin{array}{l}\text { Indonesia Irked over Singapore } \\
\text { Excessive Travel Advisory for Bali }\end{array}$ & \\
\hline & & 1.4 & $\begin{array}{l}\text { MFA Advises Singaporeans to Defer } \\
\text { Travel to Bali as Situation on Mount } \\
\text { Agung Remains Unpredictable }\end{array}$ & \\
\hline & & 1.5 & $\begin{array}{l}\text { Singapore Government Made a Travel } \\
\text { Warning about Mount Agung Eruption }\end{array}$ & \\
\hline
\end{tabular}

The first student teachers' listening fluency interaction pattern: repeated listening frequency and graded speech rate levels of average weekly similar news stories in narrow listening

The first interaction pattern found that the average listening repetitions per news story (NS) for all groups showcased graded listening repetitions results. The study results showed that the average number of participants' listening repetitions on weekly similar news stories topics in group $1(n=8)$, group $2(n=10)$, group $3(n=5)$, group $4(n=9)$, and group $5(n=11)$ were decreasing as the speech rate levels of the audio were sped up. In this case, the average number of listening repetitions were smaller as the speed of listening was sped up from slow (120 wpm), moderately slow $(130,140$, and $150 \mathrm{wpm})$, and average or a normal (160 wpm) speech level. Therefore, it can be concluded that the more they listened to similar news stories from slow to a normal speech rate level, the fewer their listening repetitions are. The pattern of interaction between participants' average number of listening repetitions and graded speech rate levels on similar news story topic can be seen in Figure 1. 


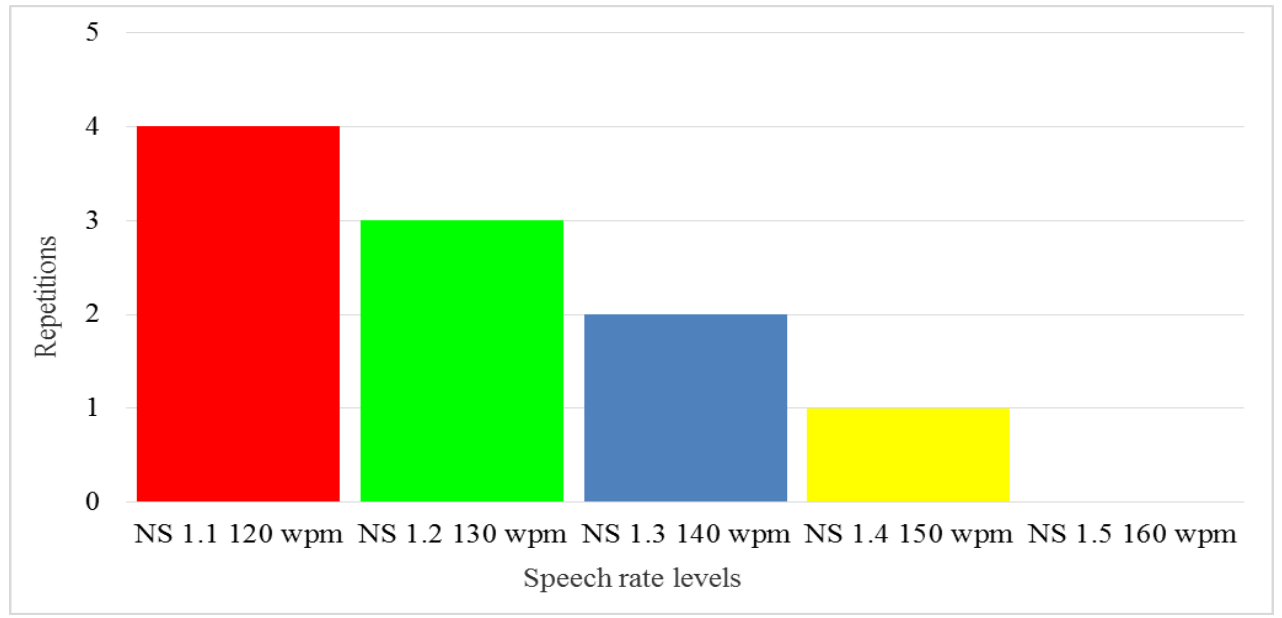

Figure 1. The average listening repetitions per news story in all groups

The second student teachers' listening fluency interaction pattern: listening fluency scores and graded speech rate levels of average weekly similar news stories in narrow listening

The second interaction pattern pointed out that the average listening fluency scores on graded speech rate levels to weekly similar news stories also showed an important finding. The participants $(n=40)$ in all groups indicated positive listening fluency scores in each stage listening fluency development activities. With this in mind, their listening fluency scores got improved when they listened to graded similar news. Notably, the groups' average listening fluency scores in similar news story topic $1.1(120 \mathrm{wpm})$ were 58 . In second similar news story topic $1.2(130 \mathrm{wpm})$, the average listening fluency scores were 66 . Besides, the average listening fluency scores in the third similar news story topic $1.3(140 \mathrm{wpm})$ were 73 . More additionally, in similar news story topic $1.4(150 \mathrm{wpm})$, the average listening fluency scores were 82 . Finally, the average listening fluency scores in similar news story topic 1.5 (160 wpm) were 90 . This finding showed that the more they listened to graded similar news stories, the better their listening fluency scores are. The summary of this interaction pattern can be seen in Figure 2.

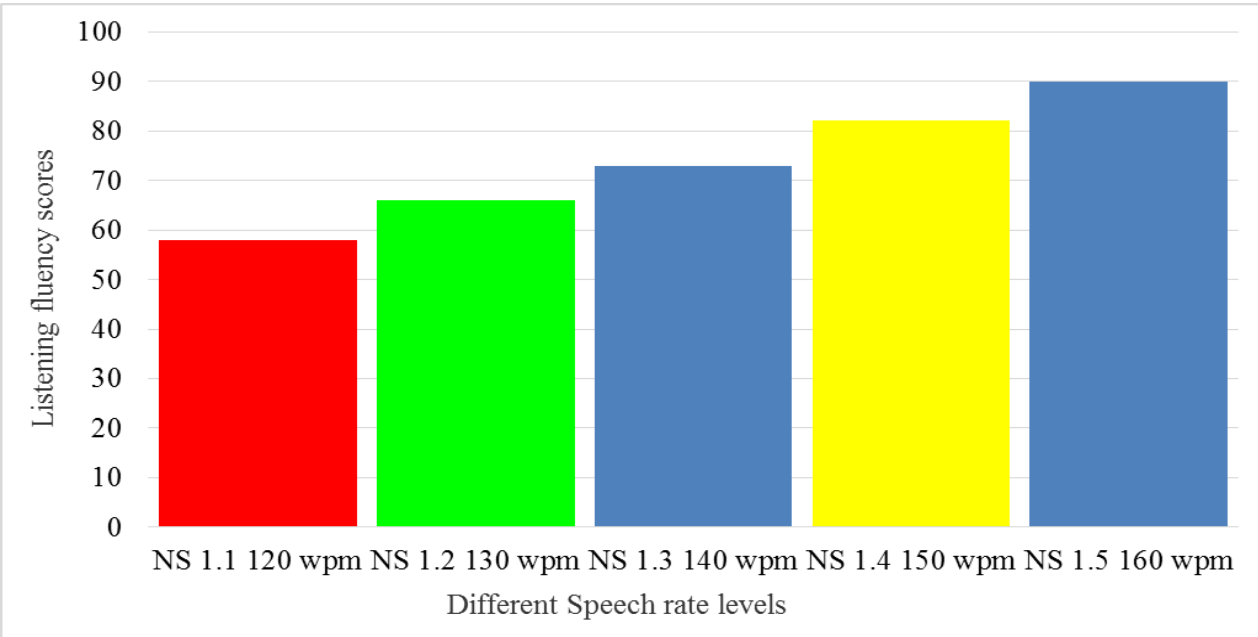

Figure 2. The average listening fluency scores in different speech rate levels for all groups The third student teachers' listening fluency interaction pattern: the average listening fluency scores in the final test by listening to similar news stories in a normal speech rate level (160 wpm) 
The third interaction pattern found that repeated graded listening in similar news stories in all groups affected the participants' final listening fluency scores. This finding specifically pointed out that they were mostly able to comprehend similar news stories topic in a normal speech rate level $(160 \mathrm{wpm})$. The average listening fluency scores were above 90 . In this language proficiency level, they have obtained good listening fluency in processing the content of similar news stores in a fast rate level. In addition to repeating the process of listening or repeated listening several times in each similar news story, they also listened to repeated structures and vocabulary for subsequent similar news stories. The summary of the third pattern can be seen in Figure 3.



Figure 3. The groups' average listening fluency scores of similar news stories topics in a normal speech rate level (160 wpm)

The challenges and opportunities to promote and include narrow listening using similar news stories in an Extensive Listening course

Investigating the challenges and opportunities of narrow listening using similar news stories in Extensive Listening course is the second issue addressed in this study. Since extensive listening is a new approach to teaching listening, especially in an initial teacher education context, its existence should be regarded as an innovation in listening instruction. Although it is still novel, the benefits of extensive exposure to meaningful language learning have been proven to support student teachers' language proficiency. However, during the implementation of a twomonth extensive listening program in the present research setting, there were several challenges and opportunities encountered by the participants. The findings were obtained from a one-to-one interview between the teacher educators and participants in the end of the study.

\section{The challenges}

The responses obtained from interview found that few participants $(n=12)$ expressed the challenges of narrow listening using similar news stories in their Extensive Listening course. The first challenge deals with the preferred headlines as the course materials. Similar news stories as authentic materials had alternatively enriched the exposure of their listening learning. However, the understandable authentic inputs that were mostly emphasizing on student teachers' needs and 
their language proficiency levels not manageable. For instance, in the case of narrow listening using similar news stories, in the beginning, teacher educators should guide student teachers to self-select authentic similar news stories from different sources and then ask them to identify using extensive listening material survey to ensure whether the preferred news stories had been comprehensible or not. However, the implementation of this preliminary task was time more consuming and made some student teachers bored. For instance, in Excerpts 1, 2, and 3, three student teachers perceived the material selection issue in this course.

Excerpt 1: "The idea of learning extensive listening using news headlines is much appreciated. I didn't learn such materials before in this course. I am happy to choose the news headline I liked most under your [teacher educators] supervision. However, I felt bored in the beginning of news headlines selection. I should ensure that the selected news headlines were really understandable using the survey. I should listen the headlines many times until I got the right ones." [Alberth/Group 1]

Excerpt 2: "Mm, I was not quite good at listening. Moreover, I tried to repeat more and more news headlines when they didn't meet my expectation. Unfortunately, I was easily demotivated when I failed to comprehend the headlines after some repetitions. Although I was finally able to collect ten headlines, for me, it's a hard effort." [Yulia/Group 2]

Excerpt 3: "Well, to reach understandable level is not that easy. I am sorry for telling you a lie that I tried to make some headlines were comprehensible. I ticked "yes" option so that I didn't need to listen more headlines." [Vita/Group 3]

Additionally, nearly from the total participants $(n=22)$ admitted that in the implementation of repeated listening in narrow listening, listening in slow speech level $(120 \mathrm{wpm})$ and listening in moderate speech level (130 wpm and $140 \mathrm{wpm}$ ) were the most challenging parts although the topics had previously been discussed in the classroom. Some student teachers felt the speaker spoke too fast, while others thought that the speakers' speech was slow (120 wpm) and the spoken vocabulary were unfamiliar. Therefore, in the beginning of listening fluency development activities via narrow listening, they needed more listening repetitions so that their listening comprehension scores were satisfying. Excerpts 4, 5, 6, and 7 showed how the participants struggled for comprehending the news headlines in the beginning of listening repetitions:

Excerpt 4: "It's quite hard to comprehend the general meaning of the news story headlines in the first listening. It seems impossible without repeating some difficult parts of news story. I just comprehended a bit in classroom listening and more listening repetitions were conducted online after classroom hours.” [Regita/Group 2]

Excerpt 5: "The first listening was challenging. The second listening was challenging too. The third listening was a bit easy. The fourth listening was easier. Each listening helped me comprehend the latter listening activities." [Antonius/Group 4]

Excerpt 6: "My listening scores in first and second listening were not satisfying. I also repeated some parts of phrases and sentences many times. I used dictionaries, browsed the information on the internet, discussed them with my peers to check my comprehension. I think approaching a normal speech level as the target of this learning is impossible if we just listen without repeating some parts of the audio." [Rosita/Group 5] 
Excerpt 7: "In the first listening, I attempted to listen to from the beginning to the end to get an initial description of the news story. In the second listening, I listened some parts that I could not understand. Each evaluation could be seen in the result of listening comprehension scores. If my score was not good [below 70], I attempted to locate on the difficult parts and listen again. When the speech levels were increased in each news story, I needed more repetitions." [Hira/Group 3]

\section{The Opportunities}

Although some challenges have been identified, there are some opportunities in promoting listening fluency using narrow listening in an Extensive Listening course in an initial teacher education context. Several participants $[n=9]$ highlighted the importance of their freedom to choose their listening materials. In active listening, student teachers are positioned as the agents of learning. In this case, they also contribute to the process of learning. In Excerpts 8, 9 , and 10 , they revealed their perceptions on this issue:

Excerpt 8: "I loved to get involved in this program as our teacher educators trusted us to choose the news stories topic we'd love to so much. The news stories stored in LMS listening audio library were also very popular in recent TV news. We were also free to choose the news stories that appropriately easy and ignore some difficult news stories." [Deksi/Group 4]

Excerpt 9: "As suggested by the teacher educators, my friends and I should participate in learning material selection by paying attention on the learning guidelines. Although this activity was too tiring in the beginning, but I was so happy because the main topic was quite famous. Therefore, when choosing similar news headlines, I should determine which one is understandable for my language proficiency and which one is not." [Hamdan/Group 2]

Excerpt 10: "Choosing our news story headlines were not difficult. We have been familiar with the main topic as they had been broadcasted lately. My topical background understanding helped my understanding a lot, especially when the audio speed in every text was increased." [Rizki/Group 1]

Excerpt 11: "I knew some of the news stories and I had also ever visited Mount Agung years ago. I knew how it's like. I was trying to connect what I was listening to and what I had experienced. This was the way I was choosing the news stories. I liked these news stories because I monitored so often this natural disaster on TV and online news portals." [Malik/Group 2]

As the above excerpts show, the participants claimed that they enjoyed the learning because they were involved in material selection. Their responses represented their views about their satisfaction on their involvement in extensive listening materials selection. They felt confident because the available news stories were up-to-date and popular in some local and international mass media. They could select the suitable news story headlines according to their language proficiency levels and teacher educators scaffolded and gave feedback to them so that they created a positive learning environment.

Meanwhile, repeated listening to similar news stories could mediate participants' listening fluency development. The data found in the listening logs indicated that repetitions helped them comprehend similar topics of new stories for different speech rates starting from a slow to a 
Arab World English Journal (AWEJ) Volume 12. Number 1. March 2021

Student Teachers' Listening Fluency Interaction Patterns

Rozak, Saleh, Bharati, \& Sutopo

normal/average rate. This finding was supported by the participants who mentioned that the more they listened to, the more they enhanced their fluency and comprehension, and the less they repeated similar news stories so that they could process the language input automatically in a normal speech rate level. $[n=10]$.

Excerpt 12: "In listening class, most of the time I could not comprehend the spoken texts expressed by native speakers of English in one listening session. I think most of my colleagues did the same. Usually, the teacher educators let us repeat playing and selflisten to the audio several times until we understood. I did note-taking during selflistening and when there were several words/phrases I didn't understand, I tried to listen to again until I caught the main points and made predictions. What I liked most was, I could self-listen to overtime so that I could control and monitor my learning." [Indra/Group 5]

Excerpt 13: "I have got two benefits from this program. First, repetitions would help me enhance my comprehension of similar news stories while developing my listening fluency. Second, because the identical vocabulary and structures among similar news stories were used many times, I could guess what came next when I should listen to similarly spoken texts. This experience guided me to listen to the actual information in the future." [Alif/Group 5]

As the above excerpts illustrated, the representative participants commenting the issue believed that the course helped them a lot improving their listening fluency and comprehension through repeating similar news stories in narrow listening. Additionally, the linked skills sequence in narrow listening could engage student teachers' participation in Extensive Listening course. It provided preparation and support for the later activities. It enabled student teachers to collaboratively use the language items from receptive to productive skills to create a communicative learning atmosphere. Some student teachers $(n=5)$ recalled the benefits of linkskills listening fluency development activities. Excerpts 14 and 15 show these perceptions:

Excerpt 14: "Frankly, listening is a boring course. But what I liked most following this course is I could express my ideas in speaking sessions both in the early pre-listening stage and while-listening stage so that I could negotiate what I had learned from previous listening stages productively with a peer. In the post-listening stage, my group and I could compose other written similar topics. It's fun.” [Sonnya/Group 4]

Excerpt 15: "My listening comprehension was better when firstly the teacher educators introduced the topic by asking us some questions and showed pictures related topic. We also had small discussions with peers to share our arguments about the topics. Also, we read the transcripts and checked some cues on dictionaries and browsed the internet. Then, we were listening to the audio while reading its written transcript. These activities helped us a lot for future out of self-listening in narrow listening." [Yusuf/Group 2]

Overall, student teachers' perceptions were very positive. They were engaged in a series of listening fluency development tasks. In this regard, they actively selected their extensive listening materials, involved in linked-skills listening fluency development tasks, and worked in groups in classroom learning, practiced improving their listening fluency independently after classroom hours, and did the evaluation to monitor their progress. 
Arab World English Journal (AWEJ) Volume 12. Number 1. March 2021

Student Teachers' Listening Fluency Interaction Patterns

Rozak, Saleh, Bharati, \& Sutopo

\section{Discussion}

Drawing on quantitative and qualitative data in a mix-method approach, participants' responses on extensive listening material survey, listening logs, listening fluency tests, and interview data, five central findings are discussed in this section. The discussions included the result of extensive listening material survey selection, the participants' listening fluency interactions patterns, and their perceptions on the opportunities and challenges to promote and include narrow listening using similar news stories in an Extensive Listening course.

\section{Extensive listening material survey selection}

This study looked at the importance of similar news stories in narrow listening. For language development, similar news stories as the authentic texts in extensive listening provide learners to afford more opportunities to develop their lexico-grammar in different communicative situations. Vandergrift and Goh (2012) argued that "learners should listen to as many different types of authentic texts as possible, on a wide variety of themes, and topics". In this study, the selection of similar news stories as extensive listening material via Google Survey was the point of departure for listening fluency development tasks. They preferred the news headline entitled "Mount Agung Eruption" reported by some local and international mass media. This headline was reported many times in late November 2017 and in the early months of 2018. During this natural disaster, some topic-related news stories headlines were also reported to become national and international attention. The main reason of choosing similar news stories was because the participants had been familiar with some related similar topics so that they could improve their background understanding for the input. Background knowledge activation while listening to the same topic helps them pay more attention to the linguistic features (Chang \& Read, 2006, 2007).

\section{The student teachers' listening fluency interaction patterns}

More specifically, the study found some interaction patterns of participants' listening fluency using similar news stories in narrow listening. The interaction patterns were dealing with the frequency of listening repetitions in each the level of speech rate, participants' listening fluency scores improvement in each speech rate level, and the proficient level of participants comprehension in listening fluency tests in the final evaluation. The more student teachers listened to similar news stories from slow to a normal speech rate level, the less their repetitions are. Chang \& Read (2006) showed that the number of repetitions were required for adequate comprehension, especially for low proficiency level students and more repetitions would help their comprehension. In this case, after they repeated some problematic parts of the news stories several times, they did not need to listen to the features of spoken language so that their listening repetitions would be decreased. In this phase of listening processing, they had been able to process the language automatically so that it influenced their global comprehension (Chang, 2011). Apart from their listening repetitions, texts familiarity and self-select news stories material selection and speech rate control were both influential in determining their frequency of repetitions. Mayora (2017) in his study found that students' freedom to select their listening materials based on the familiarity of the text genre and the repeated practices over times would aid comprehensibility while offering them the chance to be exposed to natural and realistic spoken English. Therefore, multiple exposure of similar words inter-related texts would ease their spoken lexical burden during listening process.

Another interaction pattern is student teachers' listening fluency scores in each speech rate level. This finding showed that the more they repeated graded similar news stories, the better 
their listening fluency scores are. This repeated practice mainly helps learners perform listening fluency (Nation \& Newton, 2009).This finding showcased that most of the participants likely listened to similar news stories starting from slow to a normal speech rate without teacher educator's control. This idea included in the principles of extensive listening in which they did not only self-select similar news stories in the beginning of the study, but they also selfcontrolled their listening repetitions over the times. Zao as cited in Chang (2018a) argued that students might have better comprehension when they control their speech rate during listening sessions. In the meantime, the ultimate goal of fluency development activities in this study is to reach natural speech delivered at a normal speech rate. Therefore, they needed to be scaffolded processing similar news stories from slow to a normal speech rate level. In processing slow speech rate news stories, teacher educators introduced the topic and some related vocabulary, activated their background knowledge of the topic, repeated listening, and recycled the topical vocabulary through linked skills fluency development. With this in mind, they became more efficient in word recognition which increased the speed of the listening process and thus lead a higher comprehension in each speech rate level (Chang, 2011).

Lastly, the third listening fluency interaction pattern showed that student teachers' average scores of listening fluency got improved in listening to similar news stories in a normal speech rate. This finding indicated that through scaffolded listening fluency development tasks, they were finally able to reach a normal speech rate level. Chang (2011) stated that when learners can comprehend the spoken texts in a normal speech rate, they will be more fluent in processing the listening. In this case, they could process the aural input automatically and effortlessly, restructure the words and background knowledge among texts with less hesitations. In this study, the reasonable listening performance they had reached were above 90. Chang et al. (2018a) and Dupuy (1999) argued that fluent listeners can maintain reasonable comprehension above $90 \%$ of all elements of global language processing. Furthermore, Chang (2011) also found that repeated listening practice via extensive listening is believed to gradually help L2 listeners become accustomed to listening to speech at a native speaker rate. In the same vein, monitoring student teachers' listening fluency in each speech rate level requires them to have multiple exposure to spoken form in similar news stories. Answering comprehension questions after repetition practices with different speech rate helps them ensure that their comprehension was correct (Chang \& Millet, 2013).

\section{The challenges and opportunities}

The qualitative data obtained from interview portrayed the participants' feelings, perceptions, and experiences during participating in this study. In the beginning of the study, some participants were stressful in self-selecting their news story headlines as their extensive listening materials. They should ensured that the preferred news story headlines should be at the right level. Specifically, the preferred materials should be understandable and under their respective language proficiency in extensive listening. However, choosing the appropriate learning materials according to the criteria of extensive listening material is not manageable. For some participants, the preferred authentic materials (similar news stories) are incomprehensible (Mayora, 2017). Therefore, they considered the hectic times sorting the listening materials because they were too challenging and demotivating. In contrast, the challenging materials for lower proficiency student teachers were often perceived manageable for their higher counterparts. Zhao (as cited in Chang, 2018a) argued that different individuals might perceive the same rate differently due to varying learning styles and language proficiencies. Additionally, 
Arab World English Journal (AWEJ) Volume 12. Number 1. March 2021

Student Teachers' Listening Fluency Interaction Patterns

Rozak, Saleh, Bharati, \& Sutopo

the challenge of comprehending similar news stories in the slower speech rates was because some participants were not familiar with the content. Therefore, for some lower proficiency participants, they need more repetitions than their higher proficiency counterparts (Chang \& Read, 2006). However, a higher degree of comprehension (95\% and above) is possible only after listening to the same listening materials three or four times (Renandya \& Jacobs, 2016).

Although few challenges were perceived by the participants in this study, another perspective positively revealed that they were motivated to learn extensive listening because they were involved in self-selecting their similar news stories. In extensive listening, they engaged in decision-making on what, why, and how to learn in a context both in a prescribed curriculum and a negotiated classroom curriculum because they understand better their learning needs (Widodo \& Rozak, 2016). More importantly, participants involvement in learning materials selection was relevant to extensive listening material selection guidelines in which they knew best what to learn according to their proficiency levels. Chang (2018b) highlighted two most considerations when learners were involved in determining their learning materials, such as the input materials should be exciting and appropriate to their language levels. Also, the linked skills sequence in narrow listening could engage and motivate student teachers' participation in Extensive Listening course (Nation \& Newton, 2009; and Chang \& Millet, 2013). For example in earlier activities, they were introduced the news story topics to generate their background knowledge by firstly pre teaching the keywords of the topics. With much-spoken vocabulary and background knowledge, the learners' easily comprehend the language (Chang, 2018b). Further, participants repeated each similar news story assisted by reading its transcript for reading aloud, topic-related discussions in speaking, and recycled the keywords for collaborative writing. Chang (2009) found that aural-written verification in other skills helps learners develop auditory discrimination skills, refine word recognition, and gain awareness of form-meaning relationships.

\section{Conclusion}

Anchored in narrow listening and extensive listening principles, this study looked into student teachers' listening fluency patterns of interaction by using similar news stories in narrow listening in an Extensive Listening course. Listening fluency development has been of interest in the area of English language teaching both in the ESL and EFL contexts in the last ten years. Notably, it has a significant role in developing student teachers' language proficiency in an initial teacher education in the EFL context. As they are accustomed to socializing into comprehension-based listening instruction in the classroom, they need to learn also how to process authentic spoken texts to train their automaticity for daily communicative situations. The current study raises listening fluency development tasks issue through self-selection of extensive listening materials using similar news stories, repeated listening in graded speech rate levels, and scaffolding linked-skills activities. The findings of the present study revealed that there were significant interactions patterns of participants' listening fluency using similar news stories in narrow listening. Three indicators of interactions lie on the number of listening repetitions in each speech rate level, listening fluency scores in slow and moderately slow speech rate level, and listening fluency scores in a normal speech rate level. The more the participants' listened to similar news stories from slow to a normal speech rate level, the less they made listening repetitions and their listening fluency scores become significantly increased. In this phase of listening fluency development tasks, they could improve their listening fluency scores up to a normal speech rate level. Also, some participants felt the self-selection of similar news stories in the beginning of the study was stressful and time-consuming. They also perceived repeated 
Arab World English Journal (AWEJ) Volume 12. Number 1. March 2021

Student Teachers' Listening Fluency Interaction Patterns

Rozak, Saleh, Bharati, \& Sutopo

listening in slow and moderately slow speech rate levels was not manageable because they were not familiar with the spoken vocabulary and the speakers spoke fast. Conversely, participants' involvement in materials selection and scaffolded listening fluency development through repeated listening were their positive perceptions regarding to the opportunities of the study.

The implications of the study may enrich student teachers' listening learning in an initial teacher education context. In addition to examine their listening fluency patterns of interaction, the findings of the study may raise student teachers' critical awareness how to learn best listening for developing their communicative competence. Their learning listening experiences hopefully sharp their pedagogical and language content for building their beliefs and competencies. Listening fluency inclusion in a listening curriculum is also a positive contribution in English language teaching. Apart from comprehension, listening fluency could be listening output for advanced listening instruction. With this reason, teacher educators are the important actors for curriculum reform by gradually making innovations in their classrooms. Therefore, they should change their listening instruction paradigm from teaching for comprehension or intensive listening to teaching extensive listening for communicative purposes. Although some new insights in the current study are promising, further works are required on the effectiveness of listening repetitions on similar news stories in different inputs in large scales of population. Experimental and the mix-method studies may be needed to investigate the effects of different inputs for lower and higher proficiency student teachers. Similar studies may also explore the use of listening repetitions in other authentic genres and their impacts on student teachers' listening fluency.

\section{Acknowledgment}

This article is a part of dissertation work of the first author. It was supported by a grant obtained from Direktorat Riset dan Pengabdian Masyarakat, Direktorat Jenderal Penguatan Riset dan Pengembangan, Kementrian Riset, Teknologi, dan Pendidika Tinggi (Contract

Number:083/SP2H/LT/K7/KM/2018.)

\section{Disclosure Statement}

The authors declared no potential conflicts of interest concerning the research, authorship, and publication of this article.

\section{About the Authors}

Refi Ranto Rozak, M.Pd. teaches pre-service teachers at the Department of English Education of IKIP PGRI Bojonegoro, East Java, Indonesia. He is also currently doing a Ph.D in the English Education at Universitas Negeri Semarang, based in Central Java, Indonesia. His research interests lie in the teaching of intensive and extensive listening, intensive and extensive reading, bilingual learning, and technology-enhanced language learning (TELL).

ORCID ID: https://orcid.org/0000-0001-7240-3149

Prof. Mursid Saleh, M.A., Ph.D is a professor in English Department of Universitas Negeri Semarang (UNNES). He has special interest in Language Teaching Methodology and Language Teaching Materials Development. His research entitled "The Teachers' Selection of Materials and Methods in EFL Teacher Education Classes" has brought him to get Ph.D. ORCID ID: https://orcid.org/0000-0002-4049-5322 
Arab World English Journal (AWEJ) Volume 12. Number 1. March 2021

Student Teachers' Listening Fluency Interaction Patterns

Rozak, Saleh, Bharati, \& Sutopo

Dr. Dwi Anggani Linggar Bharati, M.Pd is a lecturer of English Department, Faculty of Languages and Arts, Universitas Negeri Semarang (UNNES), Indonesia. She completed her English Education and got her doctorate in 2006. Her specialties are curriculum material development (CMD) and teaching English as a foreign language (TEFL).

Dr. Djoko Sutopo, M.Si a lecturer of English Department, Faculty of Languages and Arts, Universitas Negeri Semarang (UNNES), Indonesia. He is the author of "Journalism: Theory and Its Application". His major is in Sociolinguistics, Discourse Analysis, and Language Philosophy. ORCID ID: https://orcid.org/0000-0002-7529-2728

\section{References}

Alm, A. (2013). Extensive listening 2.0 with foreign language podcasts. Innovation in Language Learning and Teaching, 7(3), 266-280. DOI: http://dx.doi.org/10.1080/175012 29.2013.836207

Bidabadi, F. S., \& Yamat, H. (2014). Strategies employed by Iranian EFL freshman university students in extensive listening: a qualitative research. International Journal of Qualitative Studies in Education, 27(1), 23-41. DOI: http://dx.doi.org/10.10 80/09518398.2012.737042

Blyth, A. (2011). How teachers teach listening in Japan: Part 1. In M. Pinto and D. Shaffer (Eds.), PAC-KOTESOL Conference Proceedings: Advancing ELT in the Global Context. October 16-17 2010 (pp. 71-82). Seoul, Korea: KOTESOL.

Bozan, E. (2015). The Effects of Extensive Listening for Pleasure on the Proficiency Level of Foreign Language Learners in an Input-based Setting. (Unpublished MA Thesis). The University of Kansas, Lawrence, Kansas.

Chang, A.C.-S., \& Read, J. (2006). The effects of listening support on the listening performance of EFL learners. TESOL Quarterly, 40(2), 375-397. DOI: https://doi.org/10.2307/40264527

Chang A.C-S., \& Read, J. (2007). Support for foreign language listeners: its effectiveness and limitations. RELC, 38(3), 375-94. DOI: https://doi.org/10.1177/0033688207085853

Chang, A.C.-S. (2009). Gains to L2 listeners from reading while listening versus listening only in comprehending short stories. System, 37(4), 652-663. DOI: https://doi.org/10.1016/j.system.2009.09.009

Chang, A.C.-S. (2011). The effect of reading while listening to audiobooks: Listening fluency and vocabulary gain. Asian Journal of English Language Teaching, 21, 43-64.

Chang, A.C.-S. (2012). Gains to L2 learners from extensive listening: Listening development, vocabulary acquisition and perceptions of the intervention. Hong Kong Journal of Applied Linguistics, 14(1), 25-47.

Chang, A.C.-S., \& Millett, S. (2014). The effect of extensive listening on developing L2 listening fluency: Some hard evidence. ELT Journal, 68(1), 31-40. DOI: https://doi.org/10.1093/elt/cct052

Chang, A.C.-S. (2016). Teaching L2 listening: In and outside the classroom. In Renandya, W., and Widodo, H. P. (Eds.), English Language Teaching Today (pp. 97-110). Switzerland: Springer International Publishing. DOI: https://doi.org/ 10.1007/978-3-319-38834-2 
Arab World English Journal (AWEJ) Volume 12. Number 1. March 2021

Student Teachers' Listening Fluency Interaction Patterns

Rozak, Saleh, Bharati, \& Sutopo

Chang, A.C.-S., \& Millet, S. (2016). Developing L2 listening fluency through extended listening-focused activities in an extensive listening programme. RELC Journal, 47(3), 349-362. DOI: https://doi.org/10.1177/0033688216631175

Chang, A.C-S. (2018a). Speech rate in second language listening. The TESOL Encyclopedia of English Language Teaching. Edison, NJ: John Wiley \& Son.

Chang, A.C-S. (2018b). Extensive listening. The TESOL Encyclopedia of English Language Teaching. Edison, NJ: John Wiley \& Son.

Chang, A.C.-S., Millet, S., \& Renandya, W. A. (2018). Developing listening fluency through supported extensive listening practice. RELC Journal, 50(3), 422-438. DOI: https://doi.org/10.1177/0033688217751468

Chang, A.C.-S. (2019). Effects of narrow reading and listening on L2 vocabulary learning. Studies in Second Language Acquisition, 41(4), 769-794. DOI: https://doi.org/10.1017/S0272263119000032

Creswell, J. W. (2014). Research design: Qualitative, quantitative, and mixed methods approaches. ( $4^{\text {th }}$ ed.). Thousand Oaks, CA: Sage.

Ducker, N., \& Saunders, M. (2014). Facilitating extensive listening with non-graded materials in EFL programs. International Journal of Innovation in English Language Teaching and Research, 3(2), 201-214.

Dupuy, B. C. (1999). Narrow listening: An alternative way to develop and enhance listening comprehension in students of French as a foreign language. System, 27(3), 351-361. DOI: https://doi.org/10.1016/S0346-251X(99)00030-5

Krashen, S. D. (1996). The case for narrow listening. System, 24(1), 97-100. DOI: https://doi.org/10.1016/0346-251X(95)00054-N

Lee, YJ., \& Cha, KW. (2017). Listening logs for extensive listening in a self-regulated environment. Asia-Pacific Edu Res, 26(5), 271-279. DOI: https://doi.org/10.1007/s40299-017-0347-0

Masrai, A. (2019). Can L2 phonological vocabulary knowledge and listening comprehension be developed through extensive movie viewing? The case of Arab EFL learners. International Journal of Listening, 34(1), 54-69. DOI: https://doi.org/10.1080/10904018.2019.1582346

Mayora, C. A. (2017). Extensive listening in a Colombian university: Process, product, and perceptions. HOW, 24(1), 101-121. DOI: http://dx.doi.org/10.19183/how.24.1.311

Nation, I. S. P. (2007). The four strands. Innovation in Language Learning and Teaching, 1(1), 2-13. DOI: https://doi.org/10.2167/illt039.0

Nation, I. S. P., \& Newton, J. (2009). Teaching ESL/EFL Listening and Speaking. New York: Routledge. DOI: https://doi.org/10.1016/j.system.2009.11.002

Pamuji, K. D., Waring, R., \& Kurniawan, E. (2019). EFL teachers' experiences in developing L2 proficiency through extensive listening. TEFLIN Journal, 30(2), 257-273. DOI: http://dx.doi.org/10.15639/teflinjournal.v30i2/257-273

Renandya, W. A. (2011). Extensive listening in the language classroom. In Widodo, H. P., \& Cirocki, A. (eds.), Innovation and Creativity in ELT Methodology (pp. 28-41). New York: Nova Science Publisher.

Renandya, W. A., \& Farrell, T. (2011). Teacher, the tape is too fast! Extensive listening in ELT. ELT Journal, 65(1), 52-59. DOI: http://dx.doi.org/10.1093/elt/ccq015

Renandya, W. A., \& Jacob, G. M. (2016). Extensive reading and listening in the L2 classroom. In Renandya, W.A., \& Widodo, H. P. (Eds.), English Language Teaching Today (pp. 97- 
Arab World English Journal (AWEJ) Volume 12. Number 1. March 2021

110). Switzerland: Springer International Publishing. DOI: https://doi.org/10.1007/978-3319-38834-2

Renandya, W. A., \& Ivone, F. M. (2019). Extensive listening and viewing. TEFLIN Journal, 30(2), 237-256. DOI: http://dx.doi.org/10.15639/teflinjournal.v30i2/237-256

Rodrigo, V. (2003). Narrow listening and audio-library: The transitional stage in the process of developing listening comprehension in a foreign language. Mextesol Journal, 27(1), 9-25.

Rost, M. (2006). Areas of research that influence L2 listening instruction. In E. Usó-Juan \& A. Martínez-Flor (Eds.), Current trends in the development and teaching of the four language skills (pp. 47-74). Berlin: Mounton de Gruyter.

Sahrokhi, M., Bidabadi, F. S., \& Yamat, H. (2013). Voicing strategies employed in narrow listening among Iranian female freshmen. International Journal of Applied Linguistics \& English Literature, 2(3), 138-146. DOI: http://dx.doi.org/10.7575/aiac.ijalel.v.2n.3p.138

Takaesu, A. (2013). TED talks as an extensive listening resource for EAP students. Language Education in Asia, 4(2), 150-162. DOI: http://dx.doi.org/10.5746/LEiA/13/V4/I2/A05/Takaesu

Tsai, K. J. (2019). Supporting extensive listening with mobile technologies. The Journal of Asia TEFL, 16(2), 711-717. DOI: http://dx.doi.org/10.18823/asiatefl.2019.16.2.19.711

Tsang, A. (2019). Effects of narrow listening on ESL learners' pronunciation and fluency: An 'MP3 flood' programme turning mundane homework into an engaging hobby. Language Teaching Research, 23(1), 1-21. DOI: https://doi.org/10.1177/1362168819894487

Vandergrift, L., \& Goh, C. M. (2012). Teaching and learning second language listening. New York: Routledge.

Widodo, H. P., \& Rozak, R. R. (2016). Engaging student teachers in collaborative and reflective online video-assisted extensive listening in an Indonesian initial teacher education (ITE) context. Electronic Journal of Foreign Language Teaching, 13(2), 229-244.

Yeh, C-C. (2013). An investigation of a podcast learning project for extensive listening. Language Education in Asia, 4(2), 135-149. DOI: http://dx.doi.org/10.57 46/LEiA/13/V4/I2/A04/Yeh

Zeng, Y., \& Goh, C. C. M. (2018). A self-regulated learning approach to extensive listening and its impact on listening achievement and metacognitive awareness. Studies in Second Language Learning and Teaching, 8(2), 193-218. DOI: https://doi.org/10.14746/ssllt.2018.8.2.2 